\title{
Protecting the life and health of students from the negative impact of digital technologies
}

\author{
Elena Millerova*, Igor Napkhanenko, and Alexander Fedorov \\ Rostov State Transport University, 344038, Rostov on Don, Russia
}

\begin{abstract}
This article is devoted to the study of the negative aspects of the impact of the Internet on the life and health of persons who have not reached the age of majority in Russia (that is, the age of 18), as well as the criminal law and forensic possibilities of countering this. In the article, the authors goes by the types of information that are legally prohibited for distribution among minors in the Russian Federation. Having analyzed the types of this prohibited information, the authors identified exactly those types that can threaten the life and health of children. The article examines the problematic aspects of familiarizing minors with such information on the Internet, analyzes the norms of the Criminal Code of the Russian Federation, which provide for criminal liability for the distribution of this information on the Internet. The practical aspect of this study is expressed in the analysis of the issues of qualification of such crimes, their differentiation with similar elements of administrative offenses. As a result of the analysis of these criminal law norms, the authors have identified a number of gaps that need to be filled. In this regard, in order to increase the effectiveness of the criminal law struggle against the negative impact of the Internet on the life and health of minors, some amendments to the articles of the Criminal Code of the Russian Federation are proposed. The article also analyzes the forensic aspects applicable to this topic, namely, it examines some features and problems of identifying, disclosing and investigating crimes committed against minors with the use of the Internet. The author's conclusions and suggestions on this matter are expressed.
\end{abstract}

\section{Introduction}

At present, we cannot imagine our life without the global electronic network «Internet». Through this computer network, citizens perform their work in various spheres of life, spend their personal time. The younger generation uses modern gadgets even more actively than many adults, of course, using the global network «Internet». Let us be blunt about it, as some scientists accurately note, today children and teenagers literally "grow up in the digital world» [1]. Indeed, in all fairness, I must say that this global network has brought many advantages in our daily life, but there are also enough disadvantages, especially when the users of this network are children. After all, certain resources of this network negatively affect minors, their normal (in the mental and physical senses) development, and modern society, as rightly emphasized by S.V. Pestov, underestimates the danger of Internet crime

${ }^{*}$ Corresponding author: MillerovyEVEA@yandex.ru 
[2].Therefore, how can we not quote the words of the famous Russian legal scholar and outstanding specialist practitioner - chairman of the Investigative Committee of the Russian Federation A. I. Bastrykin «... every second access to the Internet is not only a blessing, but also demonstrates obvious threats to the safety of minors» [3].

In this regard, as it is interesting and at the same time accurately noted in her scientific article by O. S. Rybakova, «the digital child» requires adult representatives of society to solve the problems of its security in the information and telecommunications space [4].

The main purpose of this study is to identify the negative aspects of the impact of the Internet on the life and health of minors, which must be effectively dealt with by criminal law and forensic methods. In order to achieve this goal, the following tasks will be carried out in the study: analysis of the Russian legislation regulating the peculiarities of the distribution of information among minors; analysis of the norms providing for criminal liability for the commission of crimes that infringe on the life and health of minors with the use of the Internet; consideration of the problems of qualification of these crimes; research of criminalistic issues of detection and disclosure of such crimes.

The analysis of the works of various authors at the initial stage of this study showed that scientists mainly devote their scientific publications to the problems of distributing of one type of negative information among minors or committing one specific type of crime (committing suicide, inducement to drug use, etc.). In this work, the authors ' team will implement a comprehensive approach to the study of the problem of causing harm to the life and health of minors with the use of the Internet.

\section{Materials and methods}

Any scientific research is based on the analysis of certain materials and relies on a number of methods. In this study, the authors' team have analyzed a considerable number of scientific works of Russian and foreign scientists related to this topic. In addition, the article analyzes judicial practice, including the position of the Supreme Court of the Russian Federation on the qualification of the crimes analyzed here, as well as official statistics of the Ministry of Internal Affairs of the Russian Federation. Within the framework of the study, a number of methods of scientific cognition were used: formallogical, comparative-legal, statistical, etc.

\section{Results}

Starting directly with research, first of all, we will ask the question: What negative impact on the life and health of a minor can be carried by Internet resources, and what criminal law and forensic opportunities to counter this exist in Russia? Some scientists, having conducted their research on this issue, have come to the conclusion that there are a number of negative factors for children with excessive use of the Internet [5]. According to the results of some studies, parents also understand about the presence of a number of malicious information on the Internet for their children [6]. We, in the framework of this study, are mainly interested in those types of information distributed in relation to minors that are capable of harming the life and health of children, and therefore entail criminal liability.

First, in order to clearly understand what information is «negative» for minors regarding possible harm to their life and health, one should familiarize with the Federal Law «On the Protection of Children from Information that harms their health and development», which is directly aimed at protecting children from this kind of information [7]. 
Referring to this legal act, we see that in the Russian Federation all negative information for minors is divided into prohibited information, which is allowed to be distributed among them, and limited information. When it comes to prohibited information, everything is quite simple - such information is categorically prohibited (without any reservations) for distribution to persons under the age of 18. Limited information may be distributed to minors, but with the age criteria for the possibility of its distribution. In accordance with part 2 of Article 5 of this law, information prohibited for distribution to minors includes:

- information that encourages or incites children to commit actions that threaten their life and health, including those that lead to their suicide or actions that threaten the life and health of others;

- information that may cause children to desire to use drugs, psychotropic substances or substances of an intoxicating nature, tobacco products and alcoholic beverages, to gamble, to engage in prostitution, vagrancy or begging;

- information that justifies violence and cruelty to both humans and animals;

- information that depicts or describes sexual violence;

- information that denies family values, promotes non-traditional sexual relations, forms a disrespectful attitude towards their parents and other family members;

- information that justifies illegal behavior;

- information that contains obscene language;

- information containing pornography;

- information (personal data) about a minor who has suffered as a result of illegal actions.

As can be seen from this list of information prohibited for distribution among children, a considerable part of it is capable of harming the life and health of a minor.

Information that has restrictions on its distribution to minors is provided in part 3 of Article 5 of the above-mentioned legal act. Without describing here all types of this information, we will only say that it can be distributed among minors only in compliance with the age categories provided for this type of information by articles $7-10$ of the analyzed law. The age categories here are defined by the Russian legislators as follows: those under the age of 6 years; those who have reached the age of 6 years; those who have reached the age of 12 years; those who have reached the age of 16 years. Permission to distribute limited information among these age groups of minors is based on a fairly simple and understandable principle - the younger the age group, the fewer types of limited information are allowed to be distributed among such children.

There is a legal responsibility, both administrative and criminal for violation of the rules for the distribution of prohibited and limited information among minors in Russia. For the distribution of the most socially dangerous information, namely information prohibited by the above-mentioned law, as a rule, criminal liability is provided, and with aggravating circumstances, if the guilty person distributed such information particularly among minors. Moreover, its distribution through the Internet is also almost always currently qualified in the Criminal Code of the Russian Federation as an aggravating circumstance, which seems to be an absolutely correct position of Russian lawmakers, since this method is more socially dangerous, because it has a very wide scale of distribution.

In recent years, the Criminal Code of the Russian Federation has been strengthened by criminal law means to combat the negative impact on the life and health of minors, in particular through the Internet. So, for incitement a minor to suicide through the Internet, criminal liability is now provided for in paragraphs «a», «d» of Part 2 of Article 110 of the Criminal Code of the Russian Federation. In June 2017 The Code has been supplemented with new articles that now criminalize inducing or facilitating suicide (article 110.1) and organizing activities that incite suicide (Article 110.2). Both norms provide for the most severe criminal liability if such criminal acts are committed through the Internet (paragraph 
«d» of part 3 of Article 110.1; part 2 of Article 110.2), but with regard to the stricter criminal penalty for committing these criminal acts against minors, this is provided only in the first of these two norms (paragraph « a « of part 3 of Article 110.1), and in article 110.2 such an aggravating circumstance is not provided, which, in our opinion, is an omission of the legislators that requires compensation.

At the same time, exploring the issues of countering the inciting of minors to suicide on the Internet, one cannot but agree with the authors, who emphasize that for an effective struggle against this evil, only criminal law, forensic and other law enforcement methods are not enough. In addition, understanding and developing the most optimal measures to counteract child suicide requires a comprehensive connection of sociology, suicidology, pedagogy and psychology [8].

The distribution of information among minors in order to arouse their interest in the use of alcohol, intoxicating substances, vagrancy or begging may constitute the elements of the crime under Article 151 of the Criminal Code of the Russian Federation. As the Supreme Court of the Russian Federation explains in paragraph 42 of one of its resolutions of the Plenum [9], the involvement of a minor in the commission of anti-social actions (Article 151 of the Code) should be understood as any actions of an adult (offer, promise, persuasion, deception, threats) that are aimed at awakening the desire of a minor to commit the actions specified in the disposition of this norm.

Since minors are often involved in committing anti-social actions with the use of the Internet, the question arises why the legislators have not yet provided in the Criminal Code of the Russian Federation in article 151 qualifying aggravating circumstances for committing the actions using the Internet specified in this norm.

Inducement to use drugs or psychotropic substances, which, according to the explanations given in paragraph 27 of one of the resolutions of the Plenum of the Supreme Court of the Russian Federation [10], should be understood as any intentional actions aimed at their use (persuasion, suggestions, giving advice, deception, physical or mental coercion), is criminally liable under Article 230 of the Criminal Code of the Russian Federation. In cases where such inducement occurs using the Internet, it is more strictly criminalized and is qualified under paragraph «d» of part 2 of Article 230 of the Criminal Code of the Russian Federation, and if such inducement occurs in relation to a minor, it is even more severe (under part 3 of this article). Some in their scientific works in connection with the increase in cases of inducement to use drugs and psychotropic substances on the Internet, as recently as 2020, proposed to supplement Article 230 of the Criminal Code of the Russian Federation with the qualifying feature «...using electronic or information and telecommunications networks « [11]. Indeed, at that time, this was an actual proposal which was heard, apparently, by the legislators, since just recently, namely at the end of February 2021 , this paragraph «d " was included in part 2 of the above-mentioned criminal law norm.

Speaking about the specifics of criminal liability for inciting minors to use drugs and psychotropic substances (including with the use of the Internet), one can't help but speaking about the distinction between Article 230 of the Criminal Code of the Russian Federation and Article 6.13 of the Code of Administrative Offenses of the Russian Federation. It's not all that simple here. The fact is that Article 6.13 of this Code provides for administrative liability for propaganda or illegal advertising of drugs and psychotropic substances, which, as we understand from the above analysis of Article 230 of the Criminal Code of the Russian Federation, is very close to criminal inducement to use these drugs and substances. Moreover, article 6.13 also provides for stricter administrative liability for such propaganda with the use of the Internet. What is the fundamental difference between these two norms, and, accordingly, the difference in the actions of declination and propaganda or advertising? We share the opinion of those authors who, in their scientific works devoted to 
the problems of distinguishing between these two norms, emphasize that propaganda and advertising are aimed at an indefinite circle of people, in contrast to declination, which should always be made in relation to one specific person or several specific persons [12]. Perhaps that is why Article 6. 13 of this Code provides for stricter administrative liability for propaganda and advertising on the Internet, but does not provide for stricter liability when such propaganda or advertising is carried out specifically against minors.

However, despite the main criterion for distinguishing the criminal inclination to use drugs and psychotropic substances from their propaganda and advertising, it is still very difficult to distinguish the two above-mentioned norms in the professional activities of law enforcement agencies and in various situations of identifying these actions in their practice, as some experts reasonably note in detail in their scientific works [13].

It seems that the degree of public danger of administratively punishable actions (especially with the use of the Internet), provided for in Article 6.13 of the Code, is such that they should be subject not to administrative, but criminal liability. In this regard, in our opinion, it would be absolutely expedient and fair to provide for criminal liability for the promotion and advertising of narcotic drugs and psychotropic substances in the current Criminal Code of the Russian Federation. This can be done in two legislative ways: 1) to include criminal liability for these actions in Article 230 of this Code; 2) to provide as a new independent article of the Code. We believe that at the same time, article 6.13 should not be excluded from the Code of Administrative Offences of the Russian Federation, but it should be changed and it should be prescribed that this rule will punish legal entities administratively for propaganda and advertising of the above-mentioned means and substances. As we know, the subject of a crime under the Criminal Code of the Russian Federation can only be individuals, and under the Code of Administrative Offenses of the Russian Federation, not only individuals, but also legal entities. Thus, we will get a harmonious combination of administrative and criminal responsibility for the above actions.

In fairness, we cannot fail to mention that the above-mentioned types of information prohibited for distribution among minors, which endanger their health, do not fall under the norms of the Criminal Code of the Russian Federation, but are administratively punishable acts according to the Code of Administrative Offenses of the Russian Federation. For example, the involvement of a minor in smoking tobacco cigarettes and other nicotinecontaining products entails liability under Article 6.23 of this Code.

An analysis of the official statistics on the state of crime in Russia for 2020 suggests that a considerable number of crimes are committed using information and telecommunications technologies (including the use of the Internet), which is clearly shown in table 1. However, these official statistics do not indicate the number of such crimes committed against minors (i.e. the facts where they are victims) and how many such criminal acts are committed by minors themselves who have reached the age of criminal responsibility. It seems that this is quite important information necessary for the official publication. Without knowing these statistics, it is difficult to build an effective mechanism to counteract the negative impact of the Internet on the lives and health of minors.

Table 1. The ratio of crimes committed using the Internet in Russia in 2020 in comparison with the total number of crimes committed using information and telecommunications technologies or in the field of computer information (The state of crime in Russia (January-December 2020) // Ministry of Internal Affairs of Russia / GIAC - https://мвд.pф)

\begin{tabular}{|c|c|c|c|c|}
\hline Total & \multicolumn{3}{|c|}{ Identified by employees: } \\
\cline { 2 - 5 } crimes & of the & of intern & of federal & of other \\
& $\begin{array}{c}\text { Investigative } \\
\text { Committee of } \\
\text { the Russian } \\
\end{array}$ & alaffairs bodies & security service & bodies \\
& Federation & & & \\
\hline
\end{tabular}




\begin{tabular}{|c|c|c|c|c|}
\hline $\mathbf{5 1 0 3 9 6}$ & 1616 & 503493 & 2499 & 2778 \\
\hline $\begin{array}{c}\text { Using the } \\
\text { Internet }\end{array}$ & $\begin{array}{c}\text { of the } \\
\text { Investigative } \\
\text { Committee of } \\
\text { the Russian } \\
\text { Federation }\end{array}$ & $\begin{array}{c}\text { Of internal } \\
\text { affairs bodies }\end{array}$ & $\begin{array}{c}\text { of federal } \\
\text { security service } \\
\text { bodies }\end{array}$ & $\begin{array}{c}\text { Of other } \\
\text { departments }\end{array}$ \\
\hline 300337 & 1137 & 295616 & 1660 & 1924 \\
\hline
\end{tabular}

It is not easy to identify, disclose and even prevent criminal acts committing against minors on the Internet, primarily in cases where the offender and the victim are located in different countries [14].

The main difficulties in solving these crimes are called total virtualization and crossborder nature. In this regard, a comprehensive approach of law enforcement services in the detection, accounting and investigation of these crimes is necessary, using the latest information and technical capabilities and with close international cooperation [15].

Within the framework of this study, we cannot but mention that a significant role today in the struggle for a safe Internet for children in Russia is also played by public organizations that exercise public control in this area. Members of these organizations, who often call themselves «cyber volunteer squads» or «cyber patrol», regularly monitor the Internet. Such people have good technical skills in using computer equipment and the Internet. Some such public organizations work closely with law enforcement agencies to help them identify criminal acts committed using this network. Some authors describe in detail the activities of such public organizations in their scientific works [16].

\section{Discussion}

As part of this study, we analyzed what information that children get acquainted with on the Internet is capable of harming their life and health. According to the current legislation, such information includes: information that incites suicide or acts that harm the health of a minor or other persons; information that causes a desire to use drugs, psychotropic and intoxicating substances, alcoholic beverages and tobacco products.

Most of these types of information are criminally liable for distribution to minors (including on the Internet) in Russia. Moreover, as the analysis of the articles of the Criminal Code of the Russian Federation has shown, for the dissemination of this information on the Internet, there is a stricter criminal liability than for dissemination without using this network, as well as without using other information networks. This position of the Russian legislators in the framework of this study is recognized as correct, since the commission of the crimes analyzed here, committed against minors using the Internet, clearly has the greatest public danger than the commission of these crimes by conventional means. In some of the analyzed articles of the Criminal Code of the Russian Federation, we have identified shortcomings of the legislators that need to be filled in.

The study also shows some features and problems of detection and detection of the crimes analyzed in it, which requires additional understanding of this problem and the development of appropriate methods.

\section{Conclusions}

Thus, as a result of the analysis of all the above-mentioned issues and problems, we can suggest the following ways to improve the protection of the life and health of minors from the negative impact of the Internet on them, by making the following changes in criminal 
legislation and taking into account a number of criminalistic features of the detection, disclosure and investigation of crimes:

1. The qualification of criminal acts related to the negative impact on the life and health of minors through the use of the Internet often causes difficulties in distinguishing them from the elements of administrative offenses. This should be brought to the special attention of the persons who carry out the preliminary investigation at the stage of initiating a criminal case. The main criteria, the author's recommendations for distinguishing these elements of crimes and administrative offenses are given in the text of this study.

2. Article 110.2 of the Criminal Code of the Russian Federation should be supplemented with an aggravating circumstance qualifying guilt «in relation to a minor» .

3. It seems appropriate to supplement Article 151 of the Criminal Code of the Russian Federation with an aggravating circumstance qualifying guilt «with the use of mass media, including information and telecommunications networks (including the Internet)».

4. For the actions provided for today by Article 6.13 of the Code of Administrative Offences of the Russian Federation due to their obvious public danger, not administrative, but criminal liability should occur. In this regard, it seems fair to provide for criminal liability for the propaganda and advertising of narcotic drugs and psychotropic substances in the current Criminal Code of the Russian Federation. This can be done in two legislative ways: 1) to include criminal liability for these actions in Article 230 of the Criminal Code of the Russian Federation; 2) to provide as a new independent article of the Criminal Code of the Russian Federation.At the same time, article 6.13 should not be excluded from the Code of Administrative Offences of the Russian Federation, but it should be changed and it should be prescribed that this rule will punish legal entities administratively for propaganda and advertising of the above-mentioned means and substances.

5. The official statistics of the Ministry of Internal Affairs of Russia do not indicate how many crimes with the use of information and telecommunications technologies (including the use of the Internet) have been committed against minors (i.e., those facts where they are victims). It seems that this is quite important information necessary for the official publication. Without knowing these statistics, it is difficult to build an effective mechanism to counteract the negative impact of the Internet on the lives and health of minors. In this regard, it would be appropriatefor the Ministry of Internal Affairs of Russia to analyze such information and publish it in their annual reviews of the state of crime.

6. The difficulties of detecting and solving crimes committed against minors on the Internet mainly consist in the fact that: 1) there is total virtualization in society; 2) there is often a so-called "cross-border nature» of these crimes; 3) there are difficulties in identifying and solving such crimes due to the peculiarities of the psyche of minors, their extremely weak legal awareness and fear of law enforcement agencies (even though the minor is a victim).

In order to increase the number of detection and the conviction rate of such crimes committed against minors, it is considered necessary: 1) further improvement of the activities of specialized units of law enforcement agencies involved in the detection and disclosure of «computer» crimes; 2) development of interdepartmental and international cooperation in the detection, disclosure and investigation of such crimes; 3 ) improving the social and psychological aspects of working with minors in the prevention, detection and disclosure of crimes committed against them using the Internet; 4) improving the interaction of law enforcement agencies with representatives of public organizations engaged in civil control of the Internet.

\section{References}

1. G. Hornor, Journal of Pediatric Health Care 34, 191 (2020). 
2. S.V. Pestov, Theory of State and Law 4, 64 (2018).

3. A.I. Bastrykin, All-Russian Journal of Criminology. 1, 11 (2017).

4. O.S. Rybakova, Monitoring law enforcement 2(35), 72 (2020).

5. A. Asam, M. Samara, P. Terry, Addictive Behaviors 90, 428-436 (2019).

6. O.Y. Zotova, Y.P. Zinchenko, Procedia - Social and Behavioral Sciences 146, 61-67 (2014).

7. Federal Law No. 436-FZ of 29.12 .2010 «On the protection of children from information that harms their health and development». Legal reference system «Consultant Plus», http://www consultant.ru.

8. A.M. Bychkova, E.L..Radnaeva, All-Russian Journal of Criminology 1(12), 112 (2018).

9. Resolution of the Plenum of the Supreme Court of the Russian Federation of 01.02.2011. vol. 1 (ed. of 29.11.2016) «On the judicial practice of applying legislation regulating the features of criminal liability and punishment of minors». Reference legal system «Consultant Plus», http://www consultant.ru.

10. Resolution of the Plenum of the Supreme Court of the Russian Federation of 15.06.2006 vol. 14 «On judicial practice in cases of crimes related to narcotic drugs, psychotropic, potent and toxic substances». Reference legal system «Consultant Plus», http://www consultant.ru.

11. E.Z. Sidorova, E.Yu. Buzinskaya, Herald of the Perm Institute of the Federal Penitentiary Service of Russia 1(36), 82 (2020).

12. N.N. Zalivina, Herald of the Kaliningrad Branch of the St. Petersburg University of the Ministry of Internal Affairs of Russia 4, 144 (2018).

13. A.P. Filchenko, V.Yu. Zhandrov, Counteraction to crimes committed with the use of information and communication technologies (monograph, Filchenko A. P., Zhandrov V. P.-M., Ryazan branch of the Moscow University of the Ministry of Internal Affairs of Russia named after V. Ya. Kikotya, 2018).

14. A.A. Oganov, Herald of the Moscow University of the Ministry of Internal Affairs of Russia 2, 108 (2020).

15. V.I. Kovalenko, Scientific portal of the Ministry of Internal Affairs of Russia 3(51), 32 (2020).

16. F. Dauce, B. Loveluck, B. Ostromooukhova, A. Zaytseva, Laboratorium: Russian Review of Social Research 11(3), 46-70 (2019). 